Systematic

Botany

29(1):29-41.

2004

doi: http://dx.doi.org/10.1600/036364404772973960

\title{
Phylogenetic Relationships of Haplolepideous Mosses (Dicranidae) Inferred from rps4 Gene Sequences
}

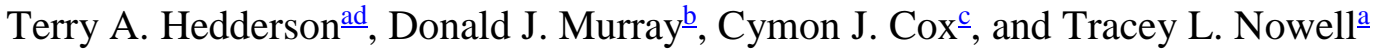

aBolus Herbarium, Department of Botany, University of Cape Town, Private Bag, Rondebosch 7701, Republic of South Africa

${ }^{\mathrm{b}}$ The Birmingham Botanical Garden, Westbourne Road, Edgbaston, Birmingham, B15 3TR U. K.

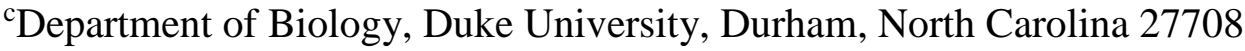

dAuthor for Correspondence ( thedders@egs.uct.ac.za)

\begin{abstract}
The haplolepideous mosses (Dicranidae) constitute a large group of ecologically and morphologically diverse species recognised primarily by having peristome teeth with a single row of cells on the dorsal surface. The reduction of sporophytes in numerous moss lineages renders circumscription of the Dicranidae problematic. Delimitation of genera and higher taxa within it has also been difficult. We analyse chloroplast-encoded rps 4 gene sequences for 129 mosses, including representatives of nearly all the haplolepideous families and subfamilies, using parsimony, likelihood and Bayesian criteria. The data set includes 59 new sequences generated for this study. With the exception of Bryobartramia, which falls within the Encalyptaceae, the Dicranidae are resolved in all analyses as a monophyletic group including the extremely reduced Archidiales and Ephemeraceae. The monotypic Catoscopium, usually assigned to the Bryidae is consistently resolved as sister to Dicranidae, and this lineage has a high posterior probability under the Bayesian criterion. Within the Dicranidae, a core clade is resolved that comprises most of the species sampled, and all analyses identify a proto-haplolepideous grade of taxa previously placed in various haplolepideous families. The data provide considerable resolution of relationships within the core Dicranidae, yielding a number of well-supported clades. These correspond only roughly to taxa that are currently recognised, and most families and orders of Dicranidae apparently are non-monophyletic under their current circumscriptions.
\end{abstract}

\section{Literature Cited}

Allen, B. 1987. On the costa of Fontinalis (Musci). Lindbergia 9:37-40. 
Buck, W. R. and B. Goffinet. 2000. Morphology and classification of mosses. Pp. 71123 in Bryophyte Biology, eds. A. J. Shaw and B. Goffinet. Cambridge: Cambridge University Press.

Capesius, I. and M. Stech. 1997. Molecular relationships within mosses based on 18S rRNA sequences. Nova Hedwigia 64:525-533.

Churchill, S. 1981. A phylogenetic analysis, classification and synopsis of the genera of the Grimmiaceae (Musci). Pp. 127- 144 in Advances in Cladistics: Proceedings of the first meeting of the Willi Hennig Society, eds. V. A. Funk and D. R. Brooks. New York: The New York Botanical Garden.

Cox, C. J. and T. A J. Hedderson. 1999. Phylogenetic relationships among the ciliate arthrodontous mosses: evidence from chloroplast and nuclear DNA sequences. Plant Systematics and Evolution 215:119-139. CrossRef

Cox, C. J., B. Goffinet, A. E. Newton, A. J. Shaw, and T. A J. Hedderson. 2000. Phylogenetic relationships among the diplolepideous-alternate mosses inferred from nuclear and chloroplast DNA sequences. The Bryologist 103:224-241. BioOne

Crum, H. A. 1994. Grimmiales. Pp. 386-415 in The moss flora of Mexico, eds. A. J. Sharp, H. A. Crum and P. M. Eckel. Memoirs of the New York Botanic Garden 69.

Crosby, M. R. 1980. The diversity and relationships of mosses. Pp. 127-144 in The mosses of North America, eds. R. J. Taylor and A. E. Leviton. San Francisco: California Academy of Science.

Edwards, S. R. 1979. Taxonomic implications of cell patterns in haplolepideous moss peristomes. Pp. 317-346 in Bryophyte systematics, eds. G. C. S. Clarke and J. G. Duckett. London: Academic Press.

Edwards, S. R. 1984. Homologies and inter-relationships of moss peristomes. Pp. 658695 in New Manual of Bryology, ed. R. M. Schuster. Nichinan: The Hattori Botanical Laboratory.

Edwards, , K, C. Johnstone, and C. Thompson. 1991. A simple and rapid method for the preparation of plant genomic DNA for PCR analysis. Nucleic Acids Research 19:1349. CrossRef, PubMed

Farris, J. S. 1969. A successive approximations approach to character weighting. Systematic Zoology 18:374-385. CrossRef

Farris, J. S. 1989. The retention index and the rescaled consistency index. Cladistics 5:417-419. CrossRef

Fleischer, M. 1902-23. Die Musci der Flora von Buitenzorg (Zugleich Launbmoosflora von Java). Vols. 1-4. Brill.

Frahm, J. P. 1991. A phenetic and cladistic study of the Campylopodioideae. Journal of the Hattori Botanical Laboratory 69:65-78.

Goffinet, B. 1998. The Rhachitheciaceae: revised generic circumscription and ordinal affinities. The Bryologist 100:425-439.

Goffinet, B. and C. J. Cox. 2000. Phylogenetic relationships among basal-most arthrodontous mosses with special emphasis on the evolutionary significance of the Funariineae. The Bryologist 103:212-223. BioOne

Goffinet, B., C. J. Cox, A. J. Shaw, and T. A. Hedderson. 2001. The Bryophyta (mosses): systematic and evolutionary inferences from a rps 4 gene (cpDNA) phylogeny. Annals of Botany 87:191-208. CrossRef

Goloboff, P. A. 1993. Estimating character weights during tree search. Cladistics 9:8391. CrossRef

Greven, H. C. 1995. Grimmia Hedw. (Grimmiaceae, Musci) in Europe. Leiden: Backhuys Publishers. 
Harvey, P. H. and M. D. Pagel. 1991. The comparative method in evolutionary biology. Oxford: Oxford University Press.

Hedderson, T. A. and R. E. Longton. 1995. Patterns of life history variation in the Funariales, Polytrichales and Pottiales. Journal of Bryology 18:639-676.

Hedderson, T. A., R. L. Chapman, and C. J. Cox. 1998. Bryophytes and the origins and diversification of land plants: new evidence from molecules. Pp. 65-77 in Bryology for the twenty-first century, eds. J. W. Bates, N. W. Ashton and J. G. Duckett. Leeds: Maney. Hedderson, T. A., C. J. Cox, and J. G. Gibbings. 1999. Phylogenetic relationships of the Wardiaceae (Musci): evidence from 18S rRNA and rps 4 gene sequences. The Bryologist 102:26-31.

Hillis, D. M. and J. J. Bull. 1993. An empirical test of bootstrapping as a method for assessing confidence in phylogenetic analyses. Systematic Biology 42:182-192. CrossRef

Huelsenbeck, J. P. and F. Ronquist. 2001. MrBayes 2.0: Bayesian Analysis of Phylogeny. Distributed by the author.

La Farge, C., A. J. Shaw, and D. H. Vitt. 2002. The circumscription of the Dicranaceae (Bryopsida) based on the chloroplast regions trnL-trnF and rps4. Systematic Botany 27:435-452.

La Farge, C., B. D. Mishler, J. A. Wheeler, D. P. Wall, K. Johannes, S. Schaffer, and A. J. Shaw. 2000. Phylogenetic relationships within the haplolepideous mosses. The Bryologist 103:257-276. BioOne

Munoz, J. and F. Pando. 2000. A world synopsis of the genus. Grimmia. Monographs in Systematic Botany from the Missouri Botanical Gardens. 83.

Newton, A. E., C. J. Cox, J. G. Duckett, J. Wheeler, B. Goffinet, T. A J. Hedderson, and B. D. Mishler. 2000. Evolution of the major moss lineages: phylogenetic analyses based on multiple gene sequences and morphology. The Bryologist 103:187-211. BioOne

Nadot, S., G. Bittar, L. Carter, R. Lacroix, and B. Lejeune. 1995. A phylogenetic analysis of monocotyledons based on the chloroplast gene rps4, using parsimony and a new numerical phenetics method. Molecular Phylogenetics and Evolution 4:257-282. CrossRef, PubMed

Philibert, H. 1984a. De l'importance du péristome pour les affinités naturelles des mousses. Revue Bryologique 11:49-52.65-72.

Philibert, H. 1984b. Études sur le péristome,. Revue Bryologique 11:80-87.

Pursell, R. A. and W. D. Reese. 1980. The taxonomic status of the Nanobryaceae (Bryopsida). The Bryologist 83:559-562.

Schofield, W. B. 1985. Introduction to Bryology. New York: Macmillan.

Shaw, A. J., B. D. Mishler, and L. E. Anderson. 1989. Peristome development in mosses in relation to systematics and evolution. IV. Haplolepideae: Ditrichaceae and Dicranaceae. The Bryologist 92:314-325.

Shoemaker, J. S., I. S. Painter, and B. S. Weir. 1999. Bayesian statistics in genetics-a guide for the uninitiated. Trends in Genetics 15:9354-358.

Snider, J. A. 1975a. A revision of the genus Archidium (Musci). Journal of the Hattori Botanical Laboratory 39:105-201.

Snider, J. A. 1975b. Sporophyte development in the genus Archidium (Musci). Journal of the Hattori Botanical Laboratory 39:85-104.

Stech, M. 1999. A reclassification of the Dicranaceae (Bryopsida) based on non-coding cpDNA sequence data. Journal of the Hattori Botanical Laboratory 86:137-159.

Stone, I. G. 1977. Some morphological and anatomical features of the monotypic genus Bryobartramia Sainsbury (Musci). Australian Journal of Botany 25:141-157. 
Swofford, D. L. 1998. PAUP*. Phylogenetic analysis using parsimony (and other methods). Version 4. Sunderland: Sinauer.

Vitt, D. H. 1984. Classification of the Bryopsida. Pp. 696-759 in New Manual of Bryology, ed. R. M. Schuster. Nichinan: The Hattori Botanical Laboratory.

Vitt, D. H., B. Goffinet, and T. A. Hedderson. 1998. The Ordinal classification of the Mosses: Questions and Answers for the 1990's. Pp. 113-123 in Bryology for the twentyfirst century, eds. J. W. Bates, N. W. Ashton and J. G. Duckett. Maney.

Williams, P. 'and others'. 1999. Gnuplot 3.71. Distributed by the authors: http://www.gnuplot.vt.edu/.

Yang, Z. 1993. Maximum likelihood estimation of phylogeny from DNA sequences when substitution rates vary over sites. Molecular Biology and Evolution 10:1396-1304. PubMed

Yang, Z. 1994. Maximum likelihood estimation of phylogeny from DNA sequences when substitution rates vary over sites: approximate methods. Journal of Molecular Evolution 39:306-314. CrossRef, PubMed

Zander, R. H. 1993. Genera of the Pottiaceae: mosses of harsh environments. Bulletin of the Buffalo Society of Natural Sciences 32:1-378.

Zander, R. H. 1998. A phylogrammatic evolutionary analysis of the moss genus Didymodon in North America north of Mexico. Bulletin of the Buffalo Society for Natural Science 36:81-115. 